Cherchyk. Lutsk: Teren [in Ukrainian].

8. Chandler, A.D. (2007) Strategy and Structure. Cambridge MIT Press [in English].

Стаття надійшла до редакції 11.11.2019 р.

УДК 631.115.8:330.341.2

Келеберда Тарас, аспірант,

Львівський національний аграрний університет, кафедра міжнародних економічних відносин та маркетингу, м. Дубляни, ORCID ID: 0000-0003-2300-4795, e-mail: tarasvkel@ukr.net

https://doi.org/10.29038/2411-4014-2019-04-74-82

\title{
НАУКОВО-МЕТОДИЧНІ АСПЕКТИ ЕКОНОМІЧНОГО МЕХАНІЗМУ СІЛЬСЬКОГОСПОДАРСЬКОГО ВИРОБНИЧОГО КООПЕРАТИВУ
}

В статті обгрунтовано необхідність опрацювання науково-методичних аспектів економічного механізму сільськогосподарського виробничого кооперативу. Розкрито сутність економічного механізму як складової господарського механізму і цілісної системи на рівні сільськогосподарського виробничого кооперативу. Обгрунтовано потребу диференційованого дослідження змісту економічного механізму підприємства на стадіях виробництва, розподілу, обміну та споживання результатів його господарської діяльності. Визначено особливу роль економічному механізму, який регулює відносини на стадії розподілу результатів господарської діяльності підприємства, для його розвитку. Розкрито зміст складових економічного механізму сільськогосподарського виробничого кооперативу на стадії розподілу результатів його господарської діяльності, до яких, зокрема, належать методика та алгоритм формування показників, отриманих внаслідок розподілу кінцевої продукції та доходу підприємства.

Ключові слова: економічний механізм, сільськогосподарський виробничий кооператив, розподіл кінцевих результатів.

Келеберда Тарас, аспирант,

Львовский национальный аграрный университет, кафедра международных экономических отношений и маркетинга, г. Дубляны

\section{НАУЧНО-МЕТОДИЧЕСКИЕ АСПЕКТЫ ЭКОНОМИЧЕСКОГО МЕХАНИЗМА СЕЛЬСЬКОХОЗЯЙСТВЕННОГО ПРОИЗВОДСТВЕННОГО КООПЕРАТИВА}

В статье обоснована необходимость разработки научно-методических аспектов экономического механизма сельскохозяйственного производственного кооператива. Раскрыта сущность экономического механизма как составляющей хозяйственного механизма и целостной системы на уровне сельскохозяйственного производственного кооператива. Обоснована необходимость дифференцированного исследования содержания экономического механизма предприятия на стадиях производства, распределения, обмена и потребления результатов его хозяйственной деятельности. Определена особая роль экономического механизма, который регулирует отношения на стадии распределения результатов хозяйственной деятельности предприятия, для его развития. Раскрыто содержание составляющих экономического механизма сельскохозяйственного производственного кооператива на стадии распределения результатов его хозяйственной деятельности, к которым, в частности, относятся методика и алгоритм формирования показателей, полученных вследствие распределения конечной продукции и дохода предприятия. 
Ключевые слова: экономический механизм, сельскохозяйственный производственный кооператив, распределение конечных результатов.

Celeberda Taras, Postgraduate,

Lviv National Agrarian University,

Department of International Economic Relations and Marketing, Dubliany

\section{SCIENTIFIC-METHODS ASPECTS OF THE ECONOMIC MECHANISM OF THE AGRICULTURAL PRODUCTION COOPERATIVE}

The economic mechanism, which functions the enterprise level, should ensure its dynamic development. Such significance of the mentioned mechanism is caused by, that he determines the degree satisfaction economic interests of participants of economic activity of the enterprise. Working out of scientific-methods aspects of the economic mechanism of enterprise acquires especially relevant for the agricultural production cooperative (further - APC) due to the fact, that: 1) this mechanism is complex and multifaceted because it is based on the unique nature of the cooperation; 2) the dynamics of the number of registered APCs in Ukraine is consistently small, as their numbers amounted to 996 units at beginning of 2018 and decreased by $23,2 \%$ in $2011-2018$.

The purpose of article is to study scientific-methods aspects of the economic mechanism of the APC taking into account the peculiarities of its manifestation at separate stages reproduction of economic activity of this enterprise.

The economic mechanism of the APC encompasses the system unity of economic forms, methods and instruments used to regulate relations in this enterprise. This mechanism may have different degrees of perfection, depending on its specific content. At same time, the economic mechanism of the APC has a different content on the stages of production, distribution, exchange and consumption of the results economic activity of this enterprise. The special role in development of the enterprise belongs to the economic mechanism that regulates relations on the stage of distribution. This is due to that the forms, methods and instruments of distribution the final results economic activity of the APC directly determine the degree satisfaction economic interests of members of the cooperative, its associate members and hired workers. The essential components of the economic mechanism of the APC on the stage of distribution of the results of its economic activity are: 1) methods and algorithm for formation indicators that determine the final results of the economic activity of the APC and are subject to further distribution; 2) methods and algorithm for formation of indicators obtained as a result of distribution of final products and income the APC.

The objective indicator of the final results of the economic activity of the APC on the initial stage of distribution of these results is the amount of final output of the enterprise for reporting year. The final indicator of distribution the final results economic activities of the APC is income that is generated on a residual basis. This indicator is subject to further distribution between the funds created at the enterprise and participants of its economic activity.

Key words: economic mechanism, agricultural production cooperative, distribution of final results.

Постановка проблеми та її значення. Динамічний розвиток підприємства до певної міри залежить від досконалості економічного механізму, який функціонує на його рівні. Таке значення цього механізму спричинена тим, що він в сукупності інших чинників розвитку підприємства визначає ступінь задоволеності економічних інтересів учасників його господарської діяльності, спонукаючи їх до конкретної дії щодо раціонального та ефективного використання ресурсного потенціалу підприємства в умовах конкурентного ринкового середовища. Розробка науковометодичних аспектів економічного механізму, який функціонує на рівні підприємства, набуває особливого значення для сільськогосподарського виробничого кооперативу (далі - СВК) у зв'язку із такими обставинами. По-перше, цей механізм є складний і багатогранний, оскільки грунтується на унікальній природі кооперації, яка як особлива форма господарювання об'єднує приватну власність та колективну форму організації праці [1, с. 15]. По-друге, попри декларовану з боку державних та регіональних органів влади фінансову та організаційну підтримку пріоритетного розвитку кооперативної форми господарювання на селі, динаміка кількості зареєстрованих СВК в Україні є стабільно невеликою, бо їх чисельність на початок 2018 р. становила 996 одиниць і за 2011-2018 рр. знизилась на 23,2\% [2].

Аналіз останніх досліджень і публікацій. Теоретико-методологічні основи функціонування економічного механізму кооперативної форми господарювання в аграрній сфері закладені О. Чаяновом, М. Туган-Барановським, М. Кондратьєвим, Є. Храпливим. У сучасний період теоретико- 
методологічні та прикладні проблеми функціонування економічного механізму кооперативної форми господарювання в аграрній сфері знайшли відображення в наукових працях В. Зіновчука [3], М. Маліка [4; 5], Л. Молдаван [6], Ф. Горбоноса [7], В. Збарського, М. Талавиря, Л. Газуди, М. Лендєла [8], Корінця Р. Я. й інших дослідників [9]. Відзначаючи цінність та багатогранність результатів досліджень, отриманих цими вченими-економістами, науково-методичні аспекти економічного механізму розвитку СВК не знайшли акцентованої уваги, що потребує поглибленої їх розробки.

Мета і завдання статті. Метою дослідження $є$ опрацювання науково-методичних аспектів економічного механізму СВК із врахуванням особливостей його прояву на окремих стадіях відтворення господарської діяльності підприємства. Відповідно до зазначеної мети вирішувались такі завдання: розкрити сутність економічного механізму як складової господарського механізму і цілісної системи на рівні СВК; встановити потребу диференційованого дослідження змісту економічного механізму підприємства на стадіях виробництва, розподілу, обміну та споживання результатів його господарської діяльності; конкретизувати зміст економічного механізму СВК на стадії розподілу кінцевих результатів господарської діяльності, зважаючи на особливу роль цієї стадії в розвитку підприємства.

Виклад основного матеріалу та обгрунтування отриманих результатів дослідження. Поняття «економічний механізм», яке 3'явилось у вітчизняній економічній літературі в 70-х роках минулого століття, розглядається як складова більш місткого поняття «господарський механізм» [10, c. 9]. Узагальнюючи певний етап дослідження сутності господарського механізму, професор С. В. Мочерний визначав його як «систему основних форм, методів і важелів використання економічних законів, вирішення суперечностей суспільного способу виробництва, реалізації власності, а також всебічного розвитку людини й узгодження ії інтересів з інтересами колективу, класу, суспільства" $[11$, c. 269]. Отже, господарський механізм охоплює форми, методи та важелі, за допомогою яких регулюються соціальні, політичні, економічні, правові, морально-етичні та інші відносини на стадіях відтворення процесу виробництва суспільних благ, а також способи організації таких відносин на рівні суспільного та корпоративного виробництва.

Серцевинною господарського механізму є економічний механізм, тому що він визначає ступінь задоволеності економічних інтересів суб'єктів господарської діяльності, спонукаючи їх до певних дій щодо раціонального та ефективного використання наявних та потенційних економічних ресурсів. Економічних механізмів може бути багато, зважаючи на те, що складовими механізму є початкове і завершальне явища, а також зовнішні та внутрішні фактори, які впливають на ці явища [12, с. 14]. Отже, досліджуючи економічний механізм на рівні окремої господарської структури 3 позиції системного підходу, його слід розглядати двояко: 1) як складову (підсистему) господарського механізму, яка функціонує на цьому рівні; 2) як цілісну систему, яка охоплює взаємопов'язані складові (механізми) нижчого рівня.

Майнова відокремленість та економічна самостійність СВК є організаційними передумовами функціонування економічного механізму як цілісної системи на його рівні. Особливості економічного механізму СВК порівняно із сільськогосподарськими підприємства інших організаційно-правових форм пов'язані із тим, що цьому підприємству (СВК) властиві окремі риси господарських товариств та приватних (фермерських) господарств. Тому автори монографії за редакцією за професора, члена-кореспондента НАAН М. А. Лендєла до особливих ознак СВК відносять: обов'язкову майнову участь членів кооперативу у формуванні його статутного фонду; обов'язкову персональну участь членів кооперативу в його діяльності; відсутні законодавчі вимоги щодо мінімального розміру пайових внесків членів кооперативу й порядку їх створення; участь членів кооперативу у його економічній діяльності на засадах автономії та господарської незалежності; самостійне визначення його внутрішньої господарської структури та відносин $[6$, с. 35 , 38].

Економічний механізм СВК, використовуючи системну єдність економічних форм, методів і важелів регулювання відносин на цьому рівні, може забезпечувати динамічний розвиток підприємства або, навпаки, стримувати цей розвиток. Тобто, такий механізм може мати різний ступінь досконалості, що залежить від його конкретного змісту. В цьому контексті слід зазначити, що змістовну наповненість економічного механізму підприємства доцільно диференціювати в залежності від його прояву на стадіях виробництва, розподілу, обміну та споживання результатів 
його господарської діяльності. Це пов'язано з тим, що на виокремлених стадіях відтворення процесу виробництва економічний механізм підприємства, відіграючи своєрідну роль в його розвитку, має різну природу свого походження.

Особлива роль в розвитку підприємства належить економічному механізму, який регулює економічні відносини на стадії розподілу, через те, що розподіл результатів виробництва, пов'язуючи між собою стадії виробництва і споживання, визначає частку та обсяги цих результатів, які отримують учасники господарської діяльності підприємства на стадії виробничого i невиробничого споживання. Тому форми, методи і важелі розподілу кінцевих результатів господарської діяльності СВК безпосередньо визначають ступінь задоволеності економічних інтересів членів кооперативу, асоційованих його членів і найманих працівників. Крім того, необхідно зазначити, що характер розподілу результатів господарської діяльності підприємства детермінований економічним змістом відносин власності, а наслідки такого розподілу функціонально залежать від кінцевих результатів господарської діяльності підприємства, отриманих ним на стадіях виробництва і обміну.

Зважаючи на особливе значення економічного механізму підприємства, який регулює економічні відносини на стадії розподілу результатів його господарської діяльності, виникає потреба конкретизувати зміст такого механізму. Складовими економічного механізму СВК на стадії розподілу результатів його господарської діяльності є: а) показники, які визначають кінцеві результати господарської діяльності СВК і підлягають подальшому розподілу, та методика їх формування; б) показники, які отримані внаслідок розподілу кінцевих результатів господарської діяльності СВК, а також методика та алгоритм їх формування (табл. 1, система рівнянь 1-4); в) показники, які отримані внаслідок розподілу доходу (чистої продукції) CВК, а також методика та алгоритм їх формування (табл. 2, система рівнянь 5-12).

Таблиия 1

Економічна природа показників, отриманих внаслідок розподілу кінцевих результатів господарської діяльності СВК, та основи методика їх формування*

\begin{tabular}{|c|c|c|}
\hline Показник & $\begin{array}{c}\text { Економічна природа } \\
\text { показника } \\
\end{array}$ & $\begin{array}{c}\text { Основи методики формування } \\
\text { показника }\end{array}$ \\
\hline $\begin{array}{l}\text { Вартісний обсяг кінцевої } \\
\text { продукції СВК за звітний } \\
\text { рік (ВКП) }\end{array}$ & 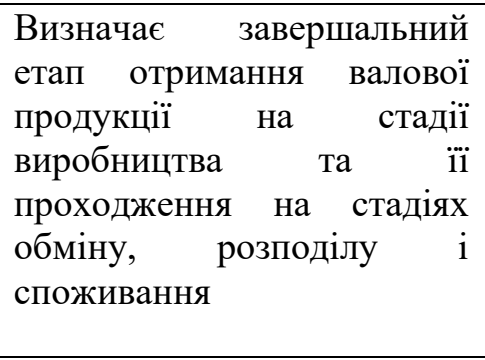 & $\begin{array}{l}\text { Охоплює вартісний } \\
\text { реалізованої продукції, виробленої } \\
\text { СВК за звітний рік, а також обсяг тієї } \\
\text { частини товарної продукції, яка } \\
\text { вироблена цим підприємством за } \\
\text { звітний рік і в подальшому } \\
\text { підлягатиме реалізації } \\
\text { справедливої вартістю** }\end{array}$ \\
\hline $\begin{array}{l}\text { Вартісний обсяг мате- } \\
\text { ріальних і прирівняних } \\
\text { до них витрат, понесених } \\
\text { СВК для виробництва і } \\
\text { збуту кінцевої продукції } \\
\text { за звітний рік }(B \Phi 3)\end{array}$ & \begin{tabular}{lrr} 
Визначає & \multicolumn{2}{r}{ завершальний } \\
етап формування & фонду \\
заміщення на & стадії \\
виробництва та & його \\
проходження на стадіях \\
обміну, розподілу \\
споживання
\end{tabular} & $\begin{array}{l}\text { Охоплює обсяги фондів заміщення } \\
\text { основних фондів, нематеріальних } \\
\text { активів i оборотних фондів, } \\
\text { спожитих для виробництва та збуту } \\
\text { кінцевої продукції СВК за звітний рік }\end{array}$ \\
\hline $\begin{array}{l}\text { Обсяг фонду оплати } \\
\text { праці найманих } \\
\text { працівників СВК в } \\
\text { частині її авансування за } \\
\text { звітний рік }(O П Н а)\end{array}$ & $\begin{array}{l}\text { Визначає процес форму- } \\
\text { вання фонду оплати праці } \\
\text { найманих працівників на } \\
\text { стадії виробництва та його } \\
\text { проходження на стадіях } \\
\text { обміну, розподілу і } \\
\text { споживання }\end{array}$ & \begin{tabular}{llc} 
Охоплює & обсяг & \multicolumn{2}{c}{ авансованого } \\
(основного) & фонду оплати & праці \\
найманих & працівників & СВК, \\
виплаченої їм за звітний рік згідно із \\
встановленими в цьому підприємстві \\
формами та системами оплати праці
\end{tabular} \\
\hline
\end{tabular}




\begin{tabular}{|c|c|c|}
\hline & & Продовження табли \\
\hline $\begin{array}{l}\text { Обсяг фонду оплати } \\
\text { праці в частині } \\
\text { преміювання найманих } \\
\text { працівників СВК за } \\
\text { кінцеві результати } \\
\text { господарської діяльності } \\
\text { за звітний рік }\left(O П H_{д}\right)\end{array}$ & 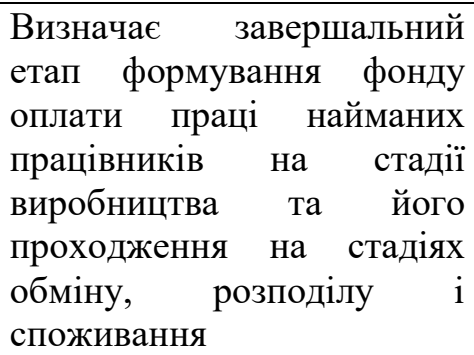 & \begin{tabular}{lll} 
Охоплює & обсяг & \multicolumn{2}{c}{ преміального } \\
(додаткового) & фонду оплати \\
найманих & працівників & СВК, \\
виплаченої їм за звітний рік згідно із \\
встановленою & системою & матері- \\
ального стимулювання за кінцеві & кезультати господарської діяльності
\end{tabular} \\
\hline $\begin{array}{l}\text { Обсяг доходу, отриманий } \\
\text { за результатами } \\
\text { господарської діяльності } \\
\text { СВК за звітний рік (ДК) }\end{array}$ & $\begin{array}{l}\text { Визначає завершальний } \\
\text { етап отримання доходу } \\
\text { (чистої продукції) СВК на } \\
\text { стадії виробництва та його } \\
\text { проходження на стадіях } \\
\text { обміну, розподілу i } \\
\text { споживання }\end{array}$ & $\begin{array}{l}\text { Формується за вирахуванням із } \\
\text { вартісних обсягів кінцевої продукції } \\
\text { СВК амортизаційних відрахувань } 3 \\
\text { необоротних активів, матеріальних і } \\
\text { прирівняних до них витрат, а також } \\
\text { фонду оплати праці найманих } \\
\text { працівників, що виплачена їм в якості } \\
\text { основної та додаткової оплати праці } \\
\text { за звітний рік }\end{array}$ \\
\hline
\end{tabular}

*Джерело: Розроблено автором на основі $[13,14]$. дату [15].

**Справедлива вартість - сума, за якою можна продати актив або оплатити зобов'язання за звичайних умов на певну

Об’єктивним показником кінцевих результатів господарської діяльності СВК на початковому етапі розподілу цих результатів є вартісний обсяг реалізованої продукції підприємства за звітний рік. Такий показник відображає завершальний етап формування обсягів валової (товарної) продукції на стадіях виробництва i товарного обміну. Попри це вартісний обсяг реалізованої продукції, виробленої підприємством за звітний рік, в неповній мірі відображає кінцеві результати його господарської діяльності, оскільки певні обсяги товарної продукції, виробленої підприємством за звітний рік, з різних причин можуть бути не реалізовані в цьому році. Тому до кінцевих результатів господарської діяльності СВК, окрім вартісного обсягу реалізованої продукції, виробленої підприємством за звітний рік, нами пропонується включати обсяг тієї частини товарної продукції, яка була вироблена підприємством за звітний рік, проте з певних причин не була реалізована в цьому році й в подальшому підлягатиме реалізації за справедливою вартістю [15].

На основі економічної природи показників, отриманих внаслідок розподілу кінцевих результатів господарської діяльності СВК, та методики їх формування (див. табл. 1), алгоритм формування цих показників описується системою рекурентних рівнянь

$$
\begin{aligned}
& B \Phi 3=B К \Pi-\left(O \Pi H_{a}+O \Pi H_{\partial}+Д K\right) \\
& B \Phi 3+O \Pi H_{a}=B К \Pi-\left(Д К+O \Pi H_{\partial}\right) \\
& B \Phi 3+O \Pi H_{a}+O \Pi H_{\partial}=B К \Pi-Д K \\
& B \Phi 3+O \Pi H_{a}+O \Pi H_{\partial}+Д К=B К \Pi .
\end{aligned}
$$

Система рівнянь 1-4 дає підставу стверджувати, що завершальним показником розподілу кінцевих результатів господарської діяльності СВК $є$ його дохід, тому що він формується за залишковим принципом. Зважаючи на такий принцип формування доходу СВК, значимим напрямом збільшення його обсягів є впровадження таких форм і систем оплати праці найманих працівників, які б стимулювала збільшення обсягів виробництва та збуту продукції визначеної якості, а також впровадження таких форм i систем матеріального преміювання найманих працівників, які б стимулювали економію матеріальних і прирівняних до них витрат.

Дохід СВК, будучи завершальним показником розподілу кінцевих результатів його господарської діяльності, підлягає подальшому розподілу між фондами, які створюються на цьому підприємстві, та учасниками його господарської діяльності (див. табл. 2). 
Економічна природа показників, отриманих внаслідок розподілу доходу (чистої продукції) СВК, та основи методика їх формування*

\begin{tabular}{|c|c|c|}
\hline Показник & $\begin{array}{c}\text { Економічна природа } \\
\text { показника } \\
\end{array}$ & $\begin{array}{c}\text { Основи методики формування } \\
\text { показника }\end{array}$ \\
\hline $\begin{array}{l}\text { Обсяг доходу, отриманий за } \\
\text { результатами господарської } \\
\text { діяльності СВК за звітний рік } \\
(Д К)\end{array}$ & $\begin{array}{l}\text { Визначає завершальний } \\
\text { етап отримання доходу } \\
\text { (чистої продукції) СВК на } \\
\text { стадії виробництва та } \\
\text { його проходження на } \\
\text { стадіях обміну, розподілу } \\
\text { і споживання }\end{array}$ & Формула 4 \\
\hline $\begin{array}{l}\text { Частина обсягу фонду } \\
\text { кооперативних виплат, яка } \\
\text { спрямована на авансування } \\
\text { участі членів СВК в його } \\
\text { господарській діяльності за } \\
\text { звітний рік }(O У Ч a)\end{array}$ & $\begin{array}{lr}\text { Визначає } & \text { процес } \\
\text { формування } & \text { фонду } \\
\text { кооперативних } & \text { виплат в } \\
\text { частині } & \text { авансування } \\
\text { участі членів СВК в його } & \text { господарській діяльності }\end{array}$ & $\begin{array}{l}\text { Охоплює частину обсягу фонду } \\
\text { кооперативних } \\
\text { спрямовану на авансування участі } \\
\text { членів СВК в його господарській } \\
\text { діяльності }\end{array}$ \\
\hline $\begin{array}{l}\text { Обсяг податків і зборів } \\
\text { (обов'язкових платежів), } \\
\text { сплачених СВК до } \\
\text { державного і місцевих } \\
\text { бюджетів за звітний рік }(O П)\end{array}$ & $\begin{array}{l}\text { Характеризує завершаль- } \\
\text { ний етап розподілу } \\
\text { доходу СВК }\end{array}$ & $\begin{array}{l}\text { Охоплює частину обсягу доходу } \\
\text { СВК, яка централізується до } \\
\text { державного бюджету різних } \\
\text { рівнів за звітний рік }\end{array}$ \\
\hline $\begin{array}{l}\text { Обсяг коштів, спрямованих на } \\
\text { погашення кредитів і сплату } \\
\text { відсотків за їх користування } \\
\text { за звітний рік (ПК) }\end{array}$ & $\begin{array}{l}\text { Характеризує } \\
\text { завершальний етап } \\
\text { розподілу доходу СВК }\end{array}$ & $\begin{array}{l}\text { Охоплює частину обсягу доходу } \\
\text { СВК, яка спрямована на } \\
\text { інвестування розвитку } \\
\text { підприємства за звітний рік }\end{array}$ \\
\hline $\begin{array}{l}\text { Обсяг коштів, спрямованих на } \\
\text { покриття збитків за результа- } \\
\text { тами господарської діяльності } \\
\text { СВК за звітний рік (ПЗ) }\end{array}$ & $\begin{array}{l}\text { Характеризує } \\
\text { завершальний етап } \\
\text { розподілу доходу СВК }\end{array}$ & $\begin{array}{l}\text { Охоплює частину обсягу доходу } \\
\text { СВК, яка спрямована на покриття } \\
\text { збитків, пов’язаних із ризиками } \\
\text { господарської діяльності } \\
\text { підприємства за звітний рік }\end{array}$ \\
\hline $\begin{array}{l}\text { Обсяг відрахувань із доходу } \\
\text { СВК до резервного та } \\
\text { спеціального фондів } \\
\text { підприємства за звітний рік } \\
(P C \Phi)\end{array}$ & $\begin{array}{l}\text { Характеризує } \\
\text { завершальний етап } \\
\text { розподілу доходу СВК }\end{array}$ & $\begin{array}{l}\text { Охоплює частину обсягу доходу } \\
\text { СВК, яка спрямована на } \\
\text { формування (поповнення) } \\
\text { резервного та спеціального фондів } \\
\text { підприємства за звітний рік }\end{array}$ \\
\hline $\begin{array}{l}\text { Частина обсягу фонду } \\
\text { кооперативних виплат, яка } \\
\text { спрямована на преміювання } \\
\text { участі членів СВК в його } \\
\text { господарській діяльності за } \\
\text { звітний рік (ОУЧд) }\end{array}$ & $\begin{array}{l}\text { Характеризує } \\
\text { завершальний етап } \\
\text { формування фонду } \\
\text { кооперативних виплат в } \\
\text { частині участі членів } \\
\text { СВК в його господарській } \\
\text { діяльності }\end{array}$ & $\begin{array}{l}\text { Охоплює частину обсягу фонду } \\
\text { кооперативних виплат, } \\
\text { спрямовану на преміювання } \\
\text { участі членів СВК в його } \\
\text { господарській діяльності }\end{array}$ \\
\hline $\begin{array}{l}\text { Обсяг фонду виплат на паї } \\
\text { асоційованим членам СВК за } \\
\text { звітний рік }\left(B \Pi_{a ч}\right)\end{array}$ & $\begin{array}{l}\text { Характеризує } \\
\text { завершальний етап } \\
\text { розподілу доходу СВК }\end{array}$ & $\begin{array}{l}\text { Охоплює частину обсягу доходу } \\
\text { СВК, яка спрямована на } \\
\text { формування фонду виплат на паї } \\
\text { асоційованим членам СВК за } \\
\text { звітний рік }\end{array}$ \\
\hline $\begin{array}{l}\text { Обсяг фонду виплат на паї } \\
\text { членам СВК за звітний рік } \\
\left(B \Pi_{4}\right)\end{array}$ & $\begin{array}{l}\text { Характеризує } \\
\text { завершальний етап } \\
\text { розподілу доходу СВК }\end{array}$ & $\begin{array}{l}\text { Охоплює частину обсягу доходу } \\
\text { СВК, яка спрямована на } \\
\text { формування фонду виплат на паї } \\
\text { членам СВК за звітний рік }\end{array}$ \\
\hline
\end{tabular}

*Джерело: розроблено автором на основі $[13,14]$. 
На основі економічної природи показників, отриманих внаслідок розподілу доходу СВК, та методики їх формування (див. табл. 2), алгоритм формування цих показників описується системою рекурентних рівнянь

$$
\begin{aligned}
& O У \Psi_{a}=Д К-\left(O \Pi+\Pi К+\Pi 3+P C \Phi+O У \Psi_{\partial}+B \Pi_{a \varphi}+B \Pi_{4}\right) ; \\
& O У \Psi_{a}+O \Pi=Д К-\left(\Pi K+\Pi 3+P C \Phi+O У \Psi_{\partial}+B \Pi_{a u}+B \Pi_{4}\right) ; \\
& O У \Psi_{a}+O \Pi+\Pi K=Д K-\left(\Pi 3+P C \Phi+O У \Psi_{\partial}+B \Pi_{a u}+B \Pi_{4}\right) ; \\
& O У \Psi_{a}+O \Pi+\Pi K+\Pi 3=Д K-\left(P C \Phi+O У \Psi_{\partial}+B \Pi_{a u}+B \Pi_{4}\right) ; \\
& O У Y_{a}+O \Pi+\Pi K+\Pi 3+P C \Phi=Д K-\left(O У Y_{\partial}+B \Pi_{a u}+B \Pi_{4}\right) ; \\
& O У \Psi_{a}+O \Pi+\Pi K+\Pi 3+P C \Phi+O У \Psi_{\partial}=Д K-\left(B \Pi_{a u}+B \Pi_{4}\right) ; \\
& O У Y_{a}+O \Pi+\Pi K+\Pi 3+P C \Phi+O У \Psi_{\partial}+B \Pi_{a u}=Д K-B \Pi_{4} ; \\
& O У Y_{a}+O \Pi+\Pi K+\Pi 3+P C \Phi+O У Y_{\partial}+B \Pi_{a \psi}+B \Pi_{4}=Д K .
\end{aligned}
$$

Системи рівнянь 5-12 показує, що варіантність розподілу доходу СВК між фондами, які створюються на підприємстві, та учасниками його господарської діяльності залежить численних чинників. Найбільш вагомими з-поміж них $є$ чинники, які визначають: а) обсяг доходу СВК і рівень рентабельності його господарської діяльності; б) обсяги фонду кооперативних виплат і тісноту зв'язку розмірів цього фонду із кінцевими результатами господарській діяльності СВК; в) обсяги обов'язкових платежів до місцевих і державного бюджетів; г) обсяги фондів соціального й економічного розвитку СВК, які створюються за рахунок власних, залучених та кредитних ресурсів; д) обсяги фондів виплат на паї асоційованим членам СВК і членам СВК.

Висновки i перспективи подальших досліджень. 1. Економічний механізм СВК, використовуючи системну єдність економічних форм, методів і важелів регулювання відносин на підприємстві, повинен забезпечувати динамічний його розвиток. Тому виникає потреба дослідження змістовної наповненості такого механізму на стадіях виробництва, розподілу, обміну та споживання результатів господарської діяльності СВК.

2. Особлива роль в розвитку СВК належить економічному механізму, який регулює економічні відносини на стадії розподілу результатів господарської діяльності підприємства, через те, що форми, методи та важелі розподілу кінцевих результатів господарської діяльності СВК безпосередньо визначають ступінь задоволеності економічних інтересів членів кооперативу, асоційованих його членів і найманих працівників.

3. Істотними складовими економічного механізму СВК на стадії розподілу результатів його господарської діяльності є: а) методика та алгоритм формування показників, які визначають кінцеві результати господарської діяльності СВК і підлягають подальшому розподілу; б) методика та алгоритм формування показників, які отримані внаслідок розподілу кінцевої продукції та доходу (чистої продукції) СВК.

4. Об’єктивним показником кінцевих результатів господарської діяльності СВК на початковому етапі розподілу таких результатів $\epsilon$ вартісний обсяг кінцевої продукції підприємства за звітний рік. Цей показник, на нашу думку, повинен охоплювати вартісний обсяг реалізованої продукції, виробленої СВК за звітний рік, а також обсяг тієї частини товарної продукції, яка вироблена цим підприємством за звітний рік, але з певних причин не була реалізована в цьому році й в подальшому підлягатиме реалізації за справедливою вартістю. Завершальним показником розподілу кінцевих результатів господарської діяльності СВК є дохід, який формується за залишковим принципом. Надалі цей показник підлягає розподілу між фондами, що створюються на підприємстві, та учасниками його господарської діяльності.

5. Варіантність розподілу доходу СВК між фондами, які створюються на підприємстві, та учасниками його господарської діяльності, залежить від численних чинників. Поглиблене вивчення таких чинників доцільно винести в рамки окремого дослідження. В цьому досліджені доречно також встановити форми, принципи та способи формування показників, що покладені в основу розподілу доходу СВК. 


\section{Джерела та література}

1. Булуй О. Г. Економічна ефективність діяльності сільськогосподарських кооперативів: автореф. дис... канд. наук. $з$ екон. та управл. підпр. (екон. с. г. і АПК): 08.00.04; Держ. агроекол. ун-т. Житомир, 2007.20 с.

2. Статистичний щорічник України за 2017 рік. / за ред. I. Є. Вернера. Київ : Державна служба статистики України, 2018. С. 245.

3. Зіновчук В. В. Організаційні основи сільськогосподарського кооперативу. Друге вид., доп. і перероб. Київ : Логос, 2001. 380 с.

4. Малік М. Й. Науково-методичне забезпечення розвитку кооперації в аграрній сфері. Економіка АПК. 2010. № 12. С. 106-111.

5. Малік М. Й. Формування та розвиток кооперативних відносин в аграрній сфері економіки України. Економіка АПК. 2014. № 7. С. 76-82.

6. Молдаван Л. В. Економічні та соціогуманістичні основи розвитку кооперативних форм господарювання в Україні. Економіка і прогнозування. 2017. № 3. С. 85-96.

7. Горбонос Ф. В. Кооперація : методологічні і методичні основи. Львів : Львівський державний аграрний університет, 2003. 264 с.

8. Корінець Р. Я., Малік М. Й., Масін В. М. та ін. Науково-практичний коментар до Закону України «Про сільськогосподарську кооперацію» та суміжних правових актів / ред. та упор. Корінець Р. Я., Малік М. В., Масін В. М., Гриценко М. П. Київ : Національна асоціація сільськогосподарських дорадчих служб України, 2018. $184 \mathrm{c}$.

9. Збарський В. К., Талавиря М. П., Газуда Л. М. Розвиток кооперативних відносин в аграрному секторі України : монографія / за ред. М. А. Лендела. Київ : НУБіП України, 2016. 307 с.

10. Мех Л. Економічна суть категорій «ринок» та «економічний механізм». Наукові записки Тернопільського державного педагогічного університету ім. Володимира Гнатюка. Серія : економіка. 2003. № 15. C. 6-11.

11. Економічна енциклопедія : у трьох томах / редкол. : С. В. Мочерний (відп. ред.) та ін. Київ : Академія, 2000. T. 1. C. 269-270.

12. Худолій Л. І. Економічний механізм формування і функціонування ринку зерна. Київ : IAE УАAН, $1998.211 \mathrm{c}$

13. Про кооперацію : Закон України № 1087-IV від 10.07.2003 із змінами. Відомості Верховної Ради України. 2004. № 5. Ст. 35. URL: https://zakon.rada.gov.ua/rada/main/1087-15 (дата звернення: 10.10.2019).

14. Про сільськогосподарську кооперацію : Закон України за станом на 20 листопада 2012 р. Biдомості Верховної Ради України. 2013. № 50. Ст. 698. URL: https://zakon.rada.gov.ua/rada/main/469/97-вр (дата звернення: 10.10.2019).

15. Положення (стандарт) бухгалтерського обліку 19 «Об'єднання підприємств». Затверджено наказом Міністерства фінансів України, 07.07.99. № 163. URL: https://zakon.rada.gov.ua/laws/show/z0499-99/ed20130809 (дата звернення: 10.10.2019).

\section{References}

1. Buluj, O. G. (2007). Ekonomichna efektyvnistj dijaljnosti siljsjkoghospodarsjkykh kooperatyviv [Economic efficiency of agricultural cooperatives]. Avtoref. dys... kand. nauk. z ekon. ta upravl. pidpr. (ekon. s. gh. i APK): 08.00.04. [in Ukrainian].

2. Verner. I. Je. (Ed.). (2017). Statystychnyj shhorichnyk Ukrajiny za 2017 rik [Statistical Yearbook of Ukraine for 2017]. Kyiv: State Statistics Service of Ukraine. 245. [in Ukrainian].

3. Zinovchuk, V. V. (2001). Orghanizacijni osnovy siljsjkoghospodarsjkogho kooperatyvu [Organizational basis of the agricultural cooperative]. (Second ed., rev.). Kiev: Logos [in Ukrainian].

4. Malik, M. J. (2010). Naukovo-metodychne zabezpechennja rozvytku kooperaciji v aghrarnij sferi [Scientific and methodological support for the development of cooperation in the agricultural sector]. Economy AIC, 12, 106-111 [in Ukrainian].

5. Malik, M. J. (2014). Formuvannja ta rozvytok kooperatyvnykh vidnosyn v aghrarnij sferi ekonomiky Ukrajiny [Formation and development of cooperative relations in agrarian sphere of economy of Ukraine]. Economy AIC, 7, 7682 [in Ukrainian].

6. Moldovan, L. V. (2017). Ekonomichni ta socioghumanistychni osnovy rozvytku kooperatyvnykh form ghospodarjuvannja v Ukrajini [Economic and sociohumanistic bases of development cooperative forms of management in Ukraine]. Economics and forecasting, 3, 85-96 [in Ukrainian].

7. Ghorbonos, F. V. (2003). Kooperacija: metodologhichni i metodychni osnovy [Cooperation: methodological and methods bases]. Lviv: Lviv State Agrarian University [in Ukrainian]. 
8. Korinets, R. Ya., Malik, M. J., Masin, V. M., Bondarchuk, V. V., Goncharenko, V. V., Grytsenko, M. P. et. al. (2018). Naukovo-praktychnyj komentar do Zakonu Ukrajiny «Pro siljsjkoghospodarsjku kooperaciju» ta sumizhnykh pravovykh aktiv [Scientific-practical commentary on the Law of Ukraine "On Agricultural Cooperation" and related legal acts]. Korinets, R. Ya., Malik, M. J., Masin, V. M. \& Grytsenko, M. P. (Eds.). Kyiv: National Association of Agricultural Advisory Services of Ukraine [in Ukrainian].

9. Zbarskyy, V. K., Talavyrya, M. P. \& Ghazuda, L. M. (2016). Rozvytok kooperatyvnykh vidnosyn v aghrarnomu sektori Ukrajiny [Development of cooperative relations in the agrarian sector of Ukraine]. M. A. Lendjel (Ed.). Kyiv: NUBiP Ukraine [in Ukrainian].

10. Mekh L. (2003). Ekonomichna sutj kateghorij «rynok» ta «ekonomichnyj mekhanizm» [The economic essence of the categories "market" and «economic mechanism»]. Scientific notes of Ternopil State Pedagogical University the name Volodymyr Hnatyuk. Series: Economics, 15, 6-15 [in Ukrainian].

11. Mocherniy, S. V. (Eds.). (2000). Ekonomichna encyklopedija : u trjokh tomakh» [The Economic Encyclopedia: in three volumes]. (V. 1). Kyiv: Academy [in Ukrainian].

12. Khudolij L. I. (1998). Ekonomichnyj mekhanizm formuvannja i funkcionuvannja rynku zerna [The economic mechanism of formation and functioning of the grain market]. Kyiv: IAE UAAN [in Ukrainian].

13. Pro kooperaciju : Zakon Ukrajiny № 1087-IV vid 10.07.2003 iz zminamy [About cooperation: Law of Ukraine № 1087-IV of 10.07.2003 as amended]. (2004). Vidomosti Verkhovnoji Rady Ukrajiny - Bulletin of the Verkhovna Rada of Ukraine, 5. St. 35. Retrieved from https://zakon.rada.gov.ua/rada/main/1087-15 [in Ukrainian].

14. Pro siljsjkoghospodarsjku kooperaciju : Zakon Ukrajiny za stanom na 20 lystopada 2012 r. [About agricultural cooperation: Law of Ukraine as of November 20, 2012]. (2013). Vidomosti Verkhovnoji Rady Ukrajiny - Bulletin of the Verkhovna Rada of Ukraine, 50. St. 698. Retrieved from https://zakon.rada.gov.ua/rada/main/469/97-вр [in Ukrainian].

15. Polozhennja (standart) bukhghaltersjkogho obliku 19 «Ob'jednannja pidpryjemstv». Zatverdzheno nakazom Ministerstva finansiv Ukrajiny, 07.07.99. № 163 [Regulation (standard) of accounting 19 «Association of enterprises». Approved by the order of the Ministry of Finance of Ukraine 07.07.99. № 163]. Retrieved from https://zakon.rada.gov.ua/laws/show/z0499-99/ed20130809 [in Ukrainian].

Стаття надійшла в редакцію 11.11.2019 р.

УДК $911.375: 005.332 .5$

Романовська Юлія, кандидат економічних наук, доцент, Винницький торговельно-економічний інститут Київського національного торговельно-економічного університету, кафедра фінансів, м. Вінниця ORCID ID 0000-0002-1099-0787 e-mail: bogdana32rom@ukr.net

\author{
https://doi.org/10.29038/2411-4014-2019-04-82-92
}

\title{
СОЦІАЛЬНО-ЕКОНОМІЧНА БЕЗПЕКА МІСТА
}

Макрополізація світу зумовила зростаюче значення ролі міст, завдяки чому доцільними вбачаються дослідження міста в межах економічної безпекології - як об'єкта соціально-економічної безпеки. Поняття «соціально-економічна безпека міста» $\epsilon$ відносно новим в економічній безпекології мезорівня, хоча ії забезпечення $є$ нагальною проблемою. Дослідження, спрямовані на визначення сутності та виявлення особливостей соціально-економічної безпеки міста, мають розпочинатися з визначення змісту поняття «соціально-економічна безпека міста», для чого сформовано відповідне предметне поле. Виходячи 3 його елементів - розгляді поняття в межах концепції «суспільства ризику» з використанням імперативів захисного 